\title{
CHRISTIAN GROES-GREEN
}

\section{FELTARBEJDETS FORPLIGTELSER}

Deltagelse og kritik blandt sateré-mawé-immigranter i Manaus, Brasilien

Tristessen har ingen ende, lykken jo (Antonio Carlos Jobim \& Vinicius de Moraes)

Med afsæt i feltarbejder i et indiansk immigrantsamfund i den brasilianske millionby Manaus belyser jeg hvorledes „deltagelsen“ som etnografisk metode fordrer et socialt engagement i det studerede samfund. Refleksioner over dette engagement har til hensigt at bidrage til en opklaring af antropologiens kritiske potentiale. Under min deltagelse i immigranternes hverdag oplevede jeg udviklingen af en gensidig forpligtelse, eller i Mauss'ke termer, en ,social kontrakt“ (Mauss 1995:15) informanterne og mig imellem: Mit engagement i deres samfund, ideer og projekter blev en nødvendig genydelse for mine informanters engagement i mit etnografiske projekt og vice versa. Nødvendigheden af mit engagement brød med illusionen om at jeg var en uinteresseret feltarbejder på dataindsamling. Vore udvekslinger af viden, arbejdskraft og sociale forbindelser var i den grad en forudsætning for at vi kunne forfølge vore respektive interesser. Mine felterfaringer peger på at engagement er en uundgåelig konsekvens af feltarbejdet som en langvarig deltagelse $i$ et afgrænset socialt rum, og derfor må indskrives som et naturligt element $\mathrm{i}$ antropologiens vidensproduktion. Ud over at være et middel til dataindsamling indebærer ,deltagelse“ en forpligtelse til at engagere sig socialt i den studerede kontekst. Mine erfaringer fra feltarbejdet i Manaus er imidlertid ikke enestående eller idiosynkratiske. Flertallet af etnografer har givet på et tidspunkt gjort sig lignende overvejelser over implikationerne af deres deltagelse i felten. Det som jeg efterstræber her er at belyse sådanne almene overvejelser over ,deltagelse“ som udgangspunkt for formuleringen af en antropologisk kritik ${ }^{1}$ (se tillige Groes-Green 2000).

\section{„Kultur“, „forfædre“ og andre håbefulde troper}

De indianske tilflyttere i Manaus, beliggende i den nordbrasilianske del af Amazon-regionen, udgør et etnisk og socialt marginaliseret mindretal. Deres sociale virkelighed er præget af fattigdom, analfabetisme, sygdom og tidlig død, samt mangel på basale nødvendigheder som medicin, el og rent vand. Til disse kummerlige forhold skal lægges 
racediskrimination af tilflytterne i en storby, hvor majoriteten er fjendtligt indstillede over for ,indianere“, der opfattes som dumme, dovne eller „folk, der hører til i junglen“. Majoriteten i Manaus er en etnisk blandingsbefolkning bestående af en hvid elite med hovedsageligt portugisiske aner, og caboclo'er, som er tilnavnet for personer af indiansk og hvid og/eller sort herkomst. Elendigheden var, forstås, allestedsnærværende og ufra-vigelig. Hvad der elendigheden til trods optog mine informanter mest, var imidlertid aspekter af det sociale liv som var fordrende for håbet om en bedre fremtid: fortællinger om forfædrenes stolte bedrifter og nedkæmpning af ,den hvide mand“ samt arbejdet for at forbedre sociale forhold og indfri idealet om at „bevare kulturen“, som forfædrene havde overleveret den.

Det viste sig at jeg gradvist var blevet en del af dette arbejde og var spundet ind $\mathrm{i}$ gensidige forpligtelser som jeg ikke kunne se bort fra. Inden længe bestod feltarbejdet ikke kun i dataindsamling, men også i at hjælpe til med madlavning, børnepasning og indkøb og derigennem bidrage til at „bevare kulturen“. Bevidstheden om sig selv som indianer med en distinkt kultur var i tidsrummet 1999-2001, hvor jeg udførte mine felt-arbejder, voksende blandt storbyens indfødte. Det kom til udtryk i dannelsen af nye indianske organisationer og foreninger samt nye kulturelle aktiviteter som rituelle danse og fremstilling af kunsthåndværk. Denne udvikling var forbundet med en øget interesse for indiansk kultur i den brasilianske og vestlige offentlighed. Det kunne spores i turisters efterspørgsel af indiansk kultur og kunst og ngo'ers velvillighed til at yde støtte til indianske projekter. En af mine yngre informanter, Moi, forklarer her den kulturelle renæssance, som gradvist tog til op gennem 1990'erne.

Det var i 1991 at min mor sagde sådan her: 'Hvorfor vender vi indianere ikke tilbage til vores kultur? Vi har en kultur, så hvorfor vender vi ikke tilbage til den, og gør de ting vi plejede at gøre: Taler vores sprog og laver vores kunsthåndværk!' Kort tid efter forenedes min mor med sine to søstre og deres børn. Baku havde seks, Araru havde tre, mor havde seks. 'Vi vil begynde at lære vores børn det som vi lærte fra vores kultur,' sagde de til os. Så begyndte vi at tale vores sprog [maué]. På det tidspunkt var jeg lige fyldt tretten år. Og sådan fortsatte vi med at leve. Vi var som fortryllede. Jeg var begejstret over at lære et nyt sprog og nye skikke. Derefter begyndte vi at spise anderledes mad end det den hvide mand spiser. Vi spiste for eksempel saúba som er en myre vi finder inde midt i skoven. Mor tog os tit med ud i skoven tæt ved lufthavnen for at samle saúba. Det var på den tid, vi begyndte at samles med andre indfødte folk i byen. Jeg kom for eksempel i kontakt med MEIAM (Movimento dos Estudantes Indígenas na Amazônia - Bevægelsen af indfødte studenter i Amazonregionen). Jeg begyndte også at komme til de møder som AMARN (Associação dos Mulheres indígenas do Alto Rio Negro - Foreningen af indfødte kvinder fra Alto Rio Negro-regionen) arrangerede. Vi blev kendte som sateré-mawé-stammen, og folk blev klar over vores eksistens. Stadig flere [turister, studerende] opsøgte os og ville vide mere om vores stamme, hvor den kom fra, og hvordan vores kultur er ...

Heldigvis for mit projekt var beboerne ikke bare villige til at tale om deres erfaringer, religion og sociale struktur. Jeg blev bedt om, endog opfordret til, at lytte til fortællinger om ,kulturen“ og dens bevarelse som den ovenfor og nedskrive, hvad jeg blev fortalt. ${ }^{2}$ Min inddragelse i deres kamp for at „,bevare kulturen“ kom helt konkret til udtryk i min deltagelse i et projekt for bygningen af et traditionelt langhus (maloca) på deres boplads $\mathrm{i}$ byens periferi. Planen med langhuset var at det skulle fungere som et sted hvor børnene kunne undervises i det traditionelle sprog mawé, og hvor beboerne kunne samles om fremstilling af kunsthåndværk og udføre deres ritualer. Jeg havde allerede under mit før- 
ste feltarbejde i 1999 hørt tale om hvordan dette langhus kunne gavne beboerne. I 2001 var ideerne blevet konkrete og de mest initiativrige beboere spurgte mig om jeg kunne hjælpe med at finde penge til projektet. Jeg hjalp sateré-mawé'erne med at udforme en ansøgning hvori de definerede projektet som ,et center for sateré-mawé'ernes kultur“. På baggrund af mit faglige netværk sendte jeg ansøgningen til IWGIA ${ }^{3}$ i København som nogle måneder efter indvilligede $\mathrm{i}$ at yde et mindre pengebel $\varnothing \mathrm{b}$ som st $\varnothing t t e$. Dermed kunne projektet begynde med indkøb og indsamling af de basale byggematerialer. Projektet skulle få afgørende konsekvenser for mit feltarbejde og dets gennemførelse.

\section{Feltarbejdets epistemologiske vendepunkt}

I forbindelse med det daglige arbejde omkring husbygningen blev det tydeligt at mine interesser som observerende etnograf ikke var i overensstemmelse med mine informanters interesser eller forventninger til mig. En formiddag hvor bygningsarbejderne var i fuld gang med at forberede træstammerne til huset, prøvede jeg at overtale nogle af mine informanter til at holde en pause, så jeg kunne lave interviews som aftalt aftenen inden. Jeg forklarede at jeg havde et møde med en sociolog på Universidade de Amazonas som jeg ikke kunne aflyse. En af arbejderne, Ramaw, som var i fuld sving med at flå barken af en stamme, så undrende på mig og sagde, ,Jamen, du er jo en del af det her, vi arbejder jo sammen, så vent lige med det andet og giv en hånd med“. Jeg havde ganske vist tidligere hjulpet med på projektet, gravet jord væk fra grunden, planeret området etc. Personligt følte jeg da også en stærk forpligtelse til at arbejde med og glemme mine interviews, men etnografen i mig var fokuseret på mit videnskabelige arbejde og min dataindsamling. Mens jeg forgæves prøvede at forklare min situation, indskød Ramaw pludselig at jeg skulle ,være med i deres byggearbejde for overhovedet at kunne forstå hvem de var“. For at understrege sin pointe sluttede han, „Kan du ikke se det, Christian, vi hjælper dig med dit studium, du er her hos os, bor med os, og så du må også hjælpe os med at bygge vores kulturhus!“ Hans udtalelser rykkede i mig og fik mig til at tænke grundigt over min rolle som antropolog, over hvad det betød ,at være med“, ,,at være del af", kort sagt over hvad det vil sige at deltage. Selvom det i dag forekommer indlysende, indså jeg at feltarbejde ikke bare er noget man udfører om, men nødvendigvis også med og for sine informanter. Selvom jeg hidtil havde deltaget ivrigt i mine informanters liv, var det i sidste ende, når aftenen faldt på og jeg skrev mine noter i hængekøjen, mit eget projekt jeg fokuserede på, ikke deres. Indledningsvis havde jeg set det som min opgave at forstå disse mennesker og måden hvorpå de forholdte sig til de udfordringer storbyen udsatte dem for. Den opgave fik Ramaws reaktion mig til at revurdere. Min deltagelse i deres liv kunne ikke blot opfattes som et middel til at opnå mine videnskabelige mål. Deltagelsen var blevet en forudsætning for at også mine informanter kunne nå deres mål.

Oprindeligt var min intention at indgå i deres lokalsamfund for at indsamle data til brug i mit projekt, det vil sige i mit speciale, og i sidste instans min videnskabelige karriere. Omvendt så sateré-mawé'erne mig som en indflydelsesrig person fra Europa med et internationalt netværk der kunne bruges i deres kamp for „kulturel overlevelse“ og sociale forbedringer. Var det, med disse forskelligartede positioner og interesser in mente, ikke naturligt at jeg øste af min økonomiske og sociale kapital samt min arbejdskraft til gengæld for deres gavmildhed og assistance? De brugte både tid og kræfter på 
mit projekt og øste af en viden der indimellem var forbundet med ambivalens, tabu og smerte. Noget endnu mere væsentligt var gået op for mig. Nemlig at det var altafgørende for mig at deltage i bygningen af langhuset for at være med i fællesskabet og leve op til lokale idealer om samarbejde og gensidighed. Samarbejde og gensidighed var uundværlige hvis vore respektive mål skulle nås. Min etnografiske undersøgelse, hvis omdrejningspunkt var udveksling og historiefortælling i sateré-mawé'ernes møde med storbyens befolkning, var selv blevet objekt for social udveksling og fortællinger om fællesskab og forpligtelser. Vores respektive projekter viste sig at være uløseligt forbundne.

De epistemologiske konsekvenser af min nye erkendelse var at den viden, som jeg skabte i felten, måtte ses som et fælles produkt af et komplekst udvekslingssystem der involverede tid, arbejde, penge og information. Desuden bidrog min deltagelse i byggeprojektet, i form af formidling af ansøgningen om finansiering, økonomisk støtte og manuelt arbejde, til at ændre udviklingen i det lokalsamfund jeg studerede. Bygningen af langhuset blev af sateré-mawé'erne opfattet som en sejr på vejen mod at sikre „kulturens bevarelse" i storbyen og dermed forfædrenes respekt. Som traditionel ramme om socialt liv i indianske landsbyer blev langhuset i flere omgange fejret som et symbol på sateré-mawé-kulturens overlevelse i storbyen.

Konsekvenserne af min deltagelse betød blandt andet at feltarbejdet og mit engagement i deres arbejde ikke kunne adskilles fra min vidensproduktion i øvrigt. Hjemvendt fra Brasilien var jeg stadig lige forpligtet over for den ,sociale kontrakt“ som mine informanter og jeg havde indgået. Og mit engagement måtte fortsætte på et andet plan hvis ikke jeg skulle løbe fra min del af kontrakten. Hvordan dette engagement kunne fortsættes i mit skriftlige arbejde, er forblevet et uafklaret spørgsmål. Selvom disse over-vejelser blev behandlet sporadisk i mit speciale, vendte de ofte tilbage i min bevidsthed som uafsluttede og ubehandlede. Mit eget skrivearbejde er dermed et let offer for den kritik, jeg fremfører i nærværende artikel, med dets mangel på refleksioner over del-tagelse og sociale forpligtelser (Groes-Green 2001, 2002a, 2002b). Kritikken som fremføres, er et fors $\emptyset \mathrm{gsvist}$ bud på hvordan jeg selv og andre antropologer i samme situation bliver bedre til at indskrive engagementet og deltagelsens nødvendighed i studiet af social elendighed.

\section{Deltagelsens indskrivning i det antropologiske projekt}

Mine eksempler fra Manaus foreslår at ,deltagelse“, og dermed også engagement og gensidighed, er uadskillelige fra den videnskabelige praksis. De er uomtvistelige forudsætninger for vor skabelse af viden og for antropologien som profession. Med henblik på at indskrive deltagelsens nødvendighed i studier af social elendighed kan Roy Rappaports artikel om „Menneskehedens evolution og antropologiens fremtid“ være et frugtbart udgangspunkt (Rappaport 1994). Rappaport slår til lyd for at vi må se antropologien, og herunder dens metoder til dataindsamling, som en interagerende og aktiv del af de samfund vi studerer, frem for at behandle den som var den en uforpligtet og uinteresseret praksis (1994:162-6, passim). Udveksling og sociale forpligtelser er grundlæggende for ethvert samfund (Mauss 1995), også dem vi kortvarigt befinder os i under feltarbejdet. Dermed er vi altid allerede del af det udvekslingssystem et samfund praktiserer, også selvom vores hensigt blot er at observere eller dokumentere samfundet og dets kultur. 
Skal vi tage videnskabens deltagelse i samfundet alvorligt, hævder Rappaport, må vi både beskæftige os med at forstå verden i dens helhed og deltage i bevarelsen af dens lokale integritet, værdier og meningsfuldhed. Via Stephen Toulmin (1982), Giambattista Vico og Gregory Bateson (1972) argumenterer han for at antropologien må inkorporere „forpligtelsen på kosmos“ i den videnskabelige praksis. Med det mener han at der skal være lige meget plads til videnskabelig „observation“ af som aktiv ,deltagelse“ i samfundets fuldendelse efter dets egne parametre. I en tid hvor videnskabens discipliner bliver stadig mere opsplittede, ser han genindførelsen af princippet om „,deltagelse“ som en måde at skabe samling hvor videnskaben opfattes som en aktiv del af den samfundsmæssige helhed (Rappaport 1994:162-6).

Disse overvejelser, mener jeg, indbyder til en gentænkning af forholdet mellem feltarbejdere og informanter; den etnografiske metode og viden som et produkt af udvekslingsforhold. For det første må gentænkningen starte med en erkendelse af at antropologisk viden er et socialt produkt, uopnåelig uden skabelsen af sociale bånd og forpligtelser. For det andet må det medtænkes at etnografens sociale forpligtelser ikke ophører ved feltarbejdets ophør, ligesom de sociale forpligtelser rækker ud over den enkelte transaktion i et udvekslingsforhold (Mauss 1995). Også i skrivearbejdet er etnografen forpligtet over for sine udvekslingspartnere i felten og må forholde sig til den sociale praksis hvorigennem alternativer til elendigheden tager form. Det er blandt andet tendensen til at fornægte det fælles projekt der opstår mellem feltarbejder og informanter som Johannes Fabian kritiserede og kaldte ,allokronisme“ (allochronism): Måden hvorpå antropologer via deres skriftlige vidensproduktion konceptuelt placerer deres informanter i en anden tid og et andet rum end dem selv. Gennem allokronismen i antropologiske arbejder benægtes det fællesskab og den intersubjektive samtidighed som antropologisk viden hviler på. Informanterne, som vi møder som subjekter i felten, bliver reduceret til objekter for vor egen produktion af videnskabelig autoritet og magt (Fabian 1983:30-5). I forlængelse af Fabians kritik foreslår Michael Jackson at den nye opmærksomhed omkring livsverdenens underprivilegerede domæner må være ensbetydende med en rekonstituering af ideen om viden som noget bydende nødvendigt for verden, snarere end blot lig med fortsat produktion af viden om verden (Jackson 1996:37). At ignorere forpligtelsen til at skabe viden for vore udvekslingspartnere er lig med et brud på den sociale kontrakt der uvægerligt etableres under feltarbejdet. Det er ikke min opgave at påpege hvordan man lever op til disse forpligtelser, hvilket må være op til den enkelte feltarbejder og dennes specifikke forhold til sine informanter. Men at feltarbejdet implicerer sociale forpligtelser, synes ubestrideligt (se også Berremans $(1968,1980)$ og Beals (1969) overvejelser over antropologens sociale forpligtelse), og det er dét faktum jeg hævder bør indarbejdes mere aktivt i det antropologiske projekt.

En af de antropologer der har beskæftiget sig indgående med problematikken omkring engagement i felten og de epistemologiske konsekvenser heraf, er Terence Turner (1991; se i øvrigt Scheper-Hughes 1992; Fabian 1991; Berreman 1980). Gennem sin årtier lange involvering i kayapó'ernes liv, som feltarbejder, har han bidraget med viden, teknologi i form af kameraer og forbundet dem med folk fra hele verden, interesserede i at støtte deres livsform og selvstændighedskamp. Med tiden blev deres kamp hans studieobjekt, og han blev et kulturelt instrument i deres kamp (Turner 1991:300-12). I sidste ende måtte han erkende at hans teori og deres selvstændighedskamp var produkter af det samme udstrakte udvekslingsforhold. Man kan se Turners refleksioner som en ideel inte- 
gration af engagement i den antropologiske vidensproduktion og dens skriftlige produkt. Forandringer i kayapó-kulturen, viser Turner, er delvist ansporet af antropologens engagement, og af kayapó'ernes ændrede forhold til nationale og internationale samfund, og omfatter desuden forandringer i deres selvbevidsthed. Fra at have opfattet sig selv som en unik stamme så de sig nu som en etnisk gruppe blandt mange hvis vigtigste fjende og samarbejdspartner ikke længere var nabostammerne, men det hvide brasilianske samfund, inklusive staten, kirken, vestlige ngo'er og antropologer. Omvendt medførte denne forandring også en fornyet bevidsthed hos antropologen om de politiske implikationer af hans deltagelse. Forandringen medførte et skift i Turners metodologiske og politiske standpunkt. Fra at se sig som en objektivt og upartisk ,deltagende observatør“ blev han en kommunikerende aktør, bevidst om at selve hans feltarbejde var en integreret del af den proces han studerede. Det ledte igen til overvejelser over hvordan repræsentation, film, tekst, kan stimulere udviklingen af kulturel selvbevidsthed og blive ressourcer i indfødte folks kamp for anerkendelse og selvstændighed. Turner blev inddraget som social ressource i filmoptagelser, oversættelse, kommunikation, og blev del af de initiativer han søgte at analysere. Grænsen mellem observatør og observerede, mellem feltarbejder og informant havde ændret sig, og gik tværs igennem Turner selv, på måder han ikke selv kunne kontrollere. Kayapó og Turner selv var blevet meddeltagere i et projekt om repræsentation, gentænkning og modstand, og deres kultur og hans teori var blevet deres fælles produkt (ibid.).

\section{For et kritisk engagement hinsides dekonstruktivismen}

Manglen på refleksioner over ,deltagelse“ og engagement i antropologiske arbejder kan illustreres ved analyser inspireret af Michel Foucaults genealogi (Foucault 1991). Herhjemme arbejder foucaultianerne ofte i skæringspunktet mellem offentlige politikker og marginale grupper der påvirkes heraf, såsom arbejdsløse, stofmisbrugere, indvandrere, fattige eller hjemløse. ${ }^{4}$ Metoden består i at dekonstruere magtens mangfoldige netværk og mikrotransformationer med henblik på at vise magtens - og dermed elendighedens historicitet. Det vil sige påvise at samfundets indretning er vilkårlig og dermed kunne være anderledes. Angiveligt grundlæggende værdier i samfundet viser sig via den Foucault'ske metode at være forankret i kontingente menneskelige handlinger, og ,det bliver klart for os, at det, der er, ikke behøver at være“ (Nielsen 2002b). Hvad angår de specifikt analyserede politikker, bruges dekonstruktionen til at vise konkrete tiltags menneskelige omkostninger. Ofte peger konklusionen på det uproduktive i en bestemt praksis og påviser en uoverensstemmelse mellem en politiks oprindelige hensigt og dens endelige resultater i og for det pågældende sociale miljø (se desuden Flyvbjerg 1991).

Trods dens heuristiske forcer med henblik på at vise magtens sociale omkostninger, fremstår dekonstruktivismen utilstrækkelig som kritisk antropologisk projekt. Simpelthen fordi dens samfundskritik mangler refleksioner over nødvendigheden af antropologens deltagelse i det kritiserede felt. Paradoksalt nok var Foucault selv bevidst om sine forpligtelser over for de felter han studerede indenfor, og deltog i en årrække i fængselsindsattes, psykiatriske patienters og homoseksuelles kamp for sociale rettigheder. Men filosoffens engagement blev aldrig eksplicit medreflekteret eller integreret $\mathrm{i}$ hans teoretiske arbejder og samfundsanalyser. ${ }^{5}$ Det er givet grunden til at hans samfunds- 
analyse står handlingslammet med hensyn til at relatere sit kritiske potentiale til den studerede kontekst. Manglen bunder givetvis i ideen om adskillelsen af den analyserende forsker og den deltagende samfundsborger. Men det er netop denne adskillelse der er vanskelig at opretholde når antropologiske analyser partout er baseret på feltarbejderens deltagelse. Det er som deltagende medborger i et samfund at feltarbejderen opnår ny antropologisk viden.

Dekontruktivismens kritik indeholder så at sige ingen løsningsforslag eller visioner der kan give mening i og for det studerede samfund. Problemet kunne for eksempel udbedres ved at give lokale drømme, håb og projekter for sociale forbedringer den fortjente opmærksomhed. Der savnes refleksioner over sociale alternativer og forbedringer på baggrund af etnografens deltagelse i felten som kunne gøre samfundskritikken relevant $\mathrm{i}$ konkrete sociale sammenhænge. Stillet over for disse spørgsmål indvender dekonstruktivisterne, at samfundsvidenskabens opgave ikke består i at fælde normative domme, men at analysere og undergrave den bestående virkelighed for at skabe nye mulighedsrum for menneskelig handling og væren (Flyvbjerg 1991; Foucault 1988). Med Foucaults ord,

Kritik handler ikke om at sige at nogle ting ikke er rigtige, som de er. Det handler om at påpege på hvilke antagelser, hvilke familiære, uudfordrede, uovervejede tankeformer, de praksisser vi accepterer, hviler på. [...] Kritik handler om [...] at vise at ting ikke er så selvindlysende som man troede, at indse at det som er accepteret som selvindlysende ikke længere vil blive accepteret som sådan (Foucault i Kritzman 1988:154; oversat fra engelsk).

Sandelig er samfundsvidenskabens rolle ikke dommerens, men ganske rigtigt analytikerens. Det forbliver imidlertid uafklaret hos Foucault hvad der skal erstatte de hidtil accepterede selvfølgeligheder. Dermed vanskeliggøres kritikken af de sociale forandringer som fremanalyseres. Så snart denne tvivl bliver erstattet med et forsvar for konkrete projekter, som det ovenfor beskrevne langhusprojekt, synes Foucault at hævde at menneskets mangfoldighed indskrænkes. På den baggrund foranlediges Foucault til at mene at den intellektuelle ikke kan have nogen programmatisk rolle i sociale transformationer (op.cit.:155). Adspurgt om han synes Antikkens livsformer kunne udgøre et alternativ til de praksisser han kritiserer i det moderne samfund, siger han,

Nej, jeg er ikke på udkig efter et alternativ. Det som jeg laver, er ikke en løsningernes historie, og det er derfor jeg ikke accepterer ordet alternativ. Jeg foretrækker at opstille proble-mernes genealogi (Foucault i Dreyfus \& Rabinow 1983:231; kursivering i originalteksten, oversat fra engelsk). ${ }^{6}$

Modsat foucaultianerne er jeg overbevist om relevansen af en lokalt forankret kritik, hvor løsningsforslag og alternativer fremkastes med afsæt i feltarbejderens kendskab til lokale forandringspotentialer og magtforhold. Det franske verbum ,,projeter“", der betyder ,at fremvise“ og ,at planlægge“, eksemplificerer det som savnes. Det kan retteligt indvendes at farerne ved den form for kritik er at den fortaber sig i en subjektiv privilegering af lokale projekter og initiativer, med de risici det måtte indebære. Her kan Kirsten Hastrups advarsel om ,engagement“ i ,de andres“ sag være på sin plads (1992:70-3). Hastrup var engageret $\mathrm{i}$ en indiansk gruppes projekt hvis formål var at sikre deres jord og uafhængighed af hvide settlers og den columbianske stat. Men eftersom indianersamfundet var splittet mellem traditionalister, der mente hendes involvering i projektet var 
udtryk for uretmæssig fremmed indblanding, og modernister, der så hende som genvej til politisk og finansiel støtte, tog hun konsekvensen og trak sig ud. Eksemplet bruger Hastrup til at gøre opmærksom på farerne ved at ville forsvare en bestemt gruppe og kæmpe deres kamp i en verden fuld af sociale modsætninger. Man risikerer blot at fremme nye modsætninger og stridigheder der i sidste ende ikke fremmer nogens sag. Etnografen ender dermed i et moralsk dilemma over hvem, om nogen, man kan tale for (ibid.).

Blandt sateré-mawé'erne i Manaus var der ligeledes interne stridigheder i immigrantsamfundet om hvad langhuset skulle bruges til, og hvem projektet var til gavn for. Mens de yngre medlemmer mente at langhuset skulle bruges til fester og spil, gik de ældre ind for at det skulle forbeholdes hellige aktiviteter, såsom ritualer, fortællinger og almen læring om kulturen, herunder fremstillingen af kunsthåndværk og jagtredskaber. Denne uenighed skabte splid i samfundet, hvor de yngre familier endte med at trække sig ud af projektet. Det betød at de mest traditionstro medlemmer blev styrket, og samfundets skrøbelige sammenhold blev svækket.

Trods de problemer jeg har beskrevet, så jeg det alligevel som min pligt at finde en måde at returnere den hjælp mine informanter havde givet mig med mit arbejde. Og jeg har da også en tro på at min støtte til deres projekt på sigt vil gavne samfundet som helhed, med den $\varnothing$ gede opmærksomhed og anerkendelse i offentligheden som projektet har skabt. Men jeg forestiller mig ikke at antropologen alene gennem sit engagement kan redde marginale grupper, såsom disse indianske immigranter, ud af deres fattigdom og elendighed. Snarere argumenterer jeg for at antropologer kan og bør forholde sig til det uomgængelige faktum at forpligtelser etableres, og så lade denne bevidsthed træde igennem i et socialt engagement såvel som i det videnskabelige arbejde. Dermed er jeg enig med Hastrup når hun skriver, ,,selvom man i den etnografiske dialog kan påberåbe sig ubrydelig solidaritet med de andre og blive deres venner og kærester, så må antropologisk viden hæve sig over venskaberne og vise verden som den er, fuld af modsigelser" (1992:73).

Et lige så væsentligt spørgsmål er imidlertid om antropologer i deres vidensproduk-tion kan undlade overvejelser over deres engagement, hvis de på godt og ondt er forplig-tede over for deres udvekslingspartnere i felten? Tilføjet dette spørgsmål gælder antro-pologi om at vise verden som den er, fuld af modsætninger - men samtidig fuld af forpligtelser. Og forpligtelser handler hverken om vold eller venskab, men om sociale alliancer. Etnografisk materiale tilvejebringes næppe, som Hastrup siger, gennem symbolsk vold over for informanterne, hvor vi indtræder i et fremmed rum som for-styrrende elementer og lejlighedsvis påfører „de andre“ smerte med vores tilstede-værelse og spørgsmål (1992:67-9). Det som foregår i felten, kan i mine øjne mere præcist beskrives som en social forhandling der fortsættes, selv når vi indarbejder det etnogra-fiske mellemværende i det tekstlige produkt. Informanter er ikke passive ofre for feltarbejderens vidensivrige overgreb. De er medspillere i en forhandlingsproces der afhænger af gensidig respekt og opofringer, og som ofte kræver af antropologen at han eller hun giver rigeligt tilbage for den viden som erhverves. Hvis en kritisk og reflekteret antropologi skal få fodfæste, må der kastes nyt lys på videnskabens forpligtelser i samfundet og dens muligheder for at komme elendigheden til livs. 


\section{Den engagerede intellektuelle}

Det vigtigste bidrag om socialvidenskabens engagement i nyere tid er kommet fra Pierre Bourdieu med bogen Contre-feux 2 - Pour un mouvement social européen (Modild) fra 2001. Her maner han socialforskere til kamp imod nyliberalismens korstog imod velfærdsstaten og dens monopolisering på den rigtige samfundsudvikling. Han skriver,

De der har det privilegium professionelt at beskæftige sig med aspekter af samfundsudviklingen, kan ikke forholde sig neutrale og passive over for udviklingen og den fremtid det hele drejer sig om (Bourdieu 2001:9).

I diskussionen om den rigtige samfundsudvikling er deltagelse i samfundsmæssige spørgsmål uomgængelig hvis videnskaben skal kunne kalde sig relevant i og for samfundet som helhed. Men Bourdieu understreger samtidig at man som kritiker kontinuerligt må underkaste sig selv og engagementet en reflekteret selvkritik. Det gælder om at være på vagt over for misbrug af sin rolle og forholde sig kritisk til egen baggrund og realitetssans, for blandt andet at undgå en genstandsløs revolutionsretorik. Det er ikke et nyt parti, Bourdieu taler for, men et uafhængigt intellektuelt kollektiv. På baggrund af kritiske samfundsanalyser vil dette kollektiv søge at udbrede en bevidsthed der kan bruges som modvægt til staten og kapitalinstitutioners dominans, som legitimeres udfra almen videnskabelig autoritet.

Som modtræk over for udviklingen kalder Bourdieu på oplysningstidens etos hvor videnskaben gik imod markedskræfterne og ville give ud af den videnskabelige viden til gavn for den sociale verden uden for elfenbenstårnet. Allerede Mauss kritiserede i Gaven nyttefilosofien og liberalismen som dominerede Europa i efterkrigstiden (1995:208). Han påpegede at den vestlige individualisme som et produkt af kapitalismen ville være skadelig for fællesskabets fred, arbejdsrytme og glæder og dermed for individet selv (ibid.). Menneskenes lykke, sagde Mauss, ligger i gensidigheden, i fælles arbejde, i den rigdom som bliver indsamlet i fællesskab og senere omfordelt ligeligt med en gensidig respekt og generøsitet som borgerne lærer via oplysning (op.cit.:217).

Bourdieu foreslår en ny organisationsform der samler forskere og politisk aktive, og som kan føre til mobilisering og handlingsorienterede initiativer på europæisk niveau. De øgede sociale skel i Europa, magtkoncentrationen i EU og kapitalstyringen bør være tilstrækkelige til at motivere en organiseret modreaktion. Efter min mening angår dette for så vidt også Latinamerika, og verdens øvrige regioner. Dog vil jeg tilføje at en modreaktion af den størrelse Bourdieu taler for, kræver at man som „,viden-skaber“" med mellemrum stiller sig skeptisk over for de grupperinger der støttes med ens viden: Hvad er deres mål? Er det retfærdigt? Kan de opnå det ønskede? Skaber mit engagement mere splittelse end det former progressive alliancer? Til dem der indvender at videnskabens neutralitet kompromitteres med et sådant engagement, svarer Bourdieu at selve skellet mellem akademisk viden og politisk engagement er grundløst. Politiske interventioner, som per definition ikke er neutrale, får netop gennemslagskraft i form af forestillinger om at de baseres på videnskabelig neutralitet, objektivitet og hæderlighed. ${ }^{7}$ Desuden kan man spørge om deltagelse i en social sammenhæng ikke altid har konsekvenser for en eller flere parter? Eller man kan spørge, som jeg har gjort her, om engagement overhovedet er undgåeligt når metoden hedder ,deltager-observation“?

Megen moderne antropologi er præget af et fokus på elendigheden i menneskelige sam- 
fund, udtrykt i studier af emner som lidelse, vold, krig, etnisk konflikt, social marginalisering og fattigdom. I 1970'erne beskæftigede mange antropologer sig med disse emner med henblik på at anvise et alternativ til elendigheden hvad enten det var via revolution, politiske reformer eller socialt engagement (se tidsskriftet Marxistisk Antropologi fra denne periode). Til forskel fra den tids radikale antropologi er fagets udøvere i dag mindre tilbøjelige til at engagere sig i at opstille alternativer til elendigheden eller diskutere løsninger på samfundsniveau. Det som mangler for at genindskrive dette engagement $\mathrm{i}$ det antropologiske projekt er ikke ,mere deltagelse“ forstået som „,deltagerobservation“ i metodisk forstand. Der mangler derimod refleksioner over og integration af deltagelsens sociale forpligtelser i den teoretiske behandling af den elendighed som studeres. Det ville, hævder jeg, desuden bidrage til en bedre forståelse af muligheder og hindringer for sociale fremskridt i sammenhænge hvor antropologer, som det hedder, studerer nedad.

\section{Noter}

1. Diskussioner om antropologiens anvendelse ligger uden for denne artikels fokus. Artiklen fokuserer på engagement som del af ,,vidensproduktion“ og videnskabeligt arbejde og ikke på antropologers virke uden for den videnskabelige praksis, som udviklingsarbejdere, konsulenter eller lignende. Det er engagement i forbindelse med erhvervelsen og produktionen af viden der diskuteres, ikke anvendelsen af antropologisk viden isoleret set.

2. En lignende situation oplevede Keesing (1992) under sit mangeårige feltarbejde blandt kwaio-folket på Solomonøerne hvor hans og deres nedskrivning af „kastom“ blev et fælles projekt i kampen for kulturel autonomi.

3. International Work Group for Indigenous Affairs.

4. Se eksempelvis Nielsen (2002a), Jöhncke (2002), Groes-Green (2001).

5. I flere interviews har Foucault til gengæld søgt at råd bod på dette misforhold, se f.eks. Kritzman (1988).

6. En udmelding der står i kontrast til Foucaults personlige engagement som talsmand for udstødte gruppers rettigheder.

7. Som eksempel angiver Bourdieu at Albert Einstein, Bertrand Russel og Andrej Sakharov udelukkende har haft deres politiske gennemslagskraft på grund af deres offentlige anseelse som hæderlige (ibid.). Herhjemme er Bjørn Lomborgs ansættelse på Center for Miljøvurdering og polemikken omkring hans viden-skabelighed et eksempel på samme mekanisme.

\section{Litteratur}

Beals, Ralph L.

1969 Politics of Social Research: An Inquiry into the Ethics and Responsibilities of Social Scientists. Chicago: Aldine.

Berreman, Gerald et al.

1968 Social Responsibilities Symposium. Current Anthropology 9:391-435.

Berreman, Gerald

1980 The Politics of Truth: Essays in Critical Anthropology. New Delhi: South Asian Publishers.

Bourdieu, Pierre

2001 Modild. For en social bevægelse i Europa. København: Hans Reitzels Forlag. 
Dreyfus, Hubert L. \& Paul Rabinow

1982 Michel Foucault: Beyond Structuralism and Hermeneutics. Chicago: University of Chicago Press.

Groes-Green, Christian

$2000 \quad$ Hinsides postmodernismen: Hen imod en kritisk engageret antropologi. Tidsskriftet Antropologi 42:105-07.

2001 Desafio Indígena a uma Politica Urbana em Manaus. Ciência \& Trópico 29(1):147-74.

2002a Tilbage til kulturen. Jordens Folk 3:50-6.

2002b Courageous Caterpillars and Images of the Whiteman: Storytelling and Exchange as Indigenous Strategies in the Face of Discrimination in Manaus, Brazil. Kandidatspeciale, Institut for Antropologi, Københavns Universitet.

Fabian, Johannes

1983 Time and the Other: How Anthropology Makes its Object. New York: Columbia University Press.

1991 Time and the Work of Anthropology. Critical Essays 1971-1991. Amsterdam: Harwood Academic Publishers.

Flyvbjerg, Bent

$1991 \quad$ Rationalitet og magt. Bind I-II. København: Akademisk Forlag.

Foucault, Michel

1972 Body/Power. I: Colin Gordon (ed.): Power/Knowledge: Selected Interviews and Other Writings 1972-1977 by Michel Foucault. New York: Pantheon Books.

1991 Nietzsche, Genealogy, History. I: Paul Rabinow (ed.): The Foucault Reader. London: Penguin Books.

Hastrup, Kirsten

1992 Det antropologiske projekt. Om forbløffelse. København: Gyldendal.

Jackson, Michael

1996 Introduction: Phenomenology, Radical Empiricism, and Anthropological Critique. I: Michael Jackson (ed.): Things as They are: New Directions in Phenomenological Anthropology.

Bloomington: Indiana University Press.

Jöhncke, Steffen

2002 Sagen under behandling. Om antropologi, stofbrugere og lodrette forbindelser. Tidsskriftet Antropologi 45:29-47.

Keesing, Roger

1992 Custom and Confrontation. The Kwaio Struggle for Cultural Autonomy. Chicago: Chicago University Press.

Kritzman, Lawrence D.

1988 Michel Foucault: Politics, Philosophy, Culture. Interviews and other Writings 1977-1984. London: Routledge.

Marxistisk Antropologi

1976-1980 Vol. 1-4. Moesgård: IMRA.

Mauss, Marcel

1995 Gaven. Utvekslingens form og årsak i arkaiske samfunn. Fagernes: Cappelen Akademisk Forlag.

Nielsen, Morten

2002a Contesting the Moralities of Leadership. Kandidatspeciale, Institut for Antropologi,

Københavns Universitet.

2002b For en opløsning af alle selvfølgeligheder. Tidsskriftet Antropologi 45:SIDETAL.

Rappaport, Roy

$1994 \quad$ Humanity's Evolution and Anthropology’s Future. I: Robert Borofsky (ed.): Assessing 
Cultural Anthropology. New York: McGraw-Hill.

Scheper-Hughes, Nancy

1995 The Primacy of the Ethical: Propositions for a Militant Anthropology. Current Anthropology 36(3):409-40.

Turner, Terence

1991

Representing, Resisting, Rethinking: Historical Transformations of Kayapo Culture and Anthropological Consciousness. I: George Stocking (ed.): Colonial Situations. Essays in the Contextualisation of Ethnographic Knowledge. Wisconsin: University of Wisconsin Press. 